\title{
КЪМ БИОГРАФИЯТА И ОБЩЕСТВЕНАТА ДЕЙНОСТ НА ДВАМА ПЛОВДИВСКИ БЪЛГАРИ - ВЪЗПИТАНИЦИ НА РИШЕЛЬОВСКИЯ ЛИЦЕЙ В ОДЕСА
}

\author{
М. Левкова-Мучинова
}

\begin{abstract}
Левкова-Мучинова М. Към биографията и обществената дейност на двама пловдивски българи - възпитаници на Ришельовския лицей в Одеса. В статията са представени животът и дейността на двама пловдивски българи, оставили значима следа в обществения живот на българите през втората и третата четвърт на XIX в. - братята Никола и Атанас Вълкович Чалики, произхождащи от богатия и влиятелен род Чалъкови. Със своите активни граждански позиции братята Чалики са едни от най-значимите представители на формиращата се новобългарска възрожденска интелигенция - добре образована и активно ангажирана в решаването на най-актуалните проблеми на своето съвремие.
\end{abstract}

Ключови думи: Българско възраждане; българска възрожденска интелигенция; Одеса; Ришельовски лицей; Пловдив; българо-руски културни и политически връзки през XIX в.

Левкова-Мучинова М. К биографии и общественной деятельности двух пловдивских болгар - воспитанников Ришельевского лицея в Одессе. В статье представлены житейские судьбы и деятельность двух пловдивских болгар, которые оставили значимый след в болгарской общественной жизни во второй и третьей четверти XIX в. - братьев Николы и Атанаса Вылкович Чалики, происходящих из богатого и влиятельного рода Чалыковых. Своими активными гражданскими позициями братья Чалики являются одними из самых значимых представителей формирующейся новоболгарской интеллигенции эпохи Возрождения - хорошо образованной и активно ангажированной в решении самых актуальных проблем своего времени.

Ключевые слова: Болгарское возрождение; болгарская интеллигенция эпохи Возрождения; Одесса; Ришельевский лицей; Пловдив; болгаро-русские культурные и политические связи XIX в.

Levkova-Muchinova M. To the biography and public activity of two Bulgarians from Plovdiv graduates from the Richelieu Lyceum of Odessa. The article presents the life and public activities of two Bulgarians from Plovdiv, who have left a significant mark in the Bulgarian public life in the second and third quarter of the $19^{\text {th }}$ century - the brothers Nikola and Atanas Valkovich Chaliki, originating from the rich and influential family of Chalakovi. Due to their active citizenship the Chaliki brothers are two of the most important representatives of the emerging Bulgarian Revival intellectuals - well educated and actively engaged in solving the most pressing issues of their time.

Keywords: Bulgarian Revival; Bulgarian Revival intellectuals; Odessa; Richelieu Lyceum, BulgarianRussian cultural and political relations during the $19^{\text {th }}$ century.

През XIX в. в търсене на по-добри възможности за образование много българи се насочват към учебните заведения извън пределите на Османската империя - в Русия, Сърбия, Дунавските княжества, Гърция и страните от Централна и Западна Европа. През 30-40-те години на века все повече българи продължават образованието си в духовни и светски училища в Руската империя, за което допринася целенасочената политика на руските държавни органи за утвърждаване на руското културно влияние върху балканските славяни и най-вече българите ${ }^{1}$. Като един от основните образователни центрове за българските младежи в Русия се налага черноморският град Одеса - както поради географската близост с намиращите се под османска власт български земи, така и поради присъствието на значителна и обществено активна българска колония в града ${ }^{2}$. Едно от най-авторитетните одески учебни заведения е откритият през 1817 г. Ришельовски лицей, който през 60-те години на XIX в. прераства в Новорусийски университет ${ }^{3}$.

Настоящата статия има за цел да представи основните факти от биографията и обществената дейност на двама от възпитаниците на Ришельовския лицей в Одеса, оставили значима следа в обществения живот на българите през втората и третата четвърт на XIX столетие. Братята Никола и Атанас Вълкович Чалъкови (Чалики) принадлежат към известния със стопанската и обществено-политическата си дейност копривщенско-пловдивски род Чалъкови4 ${ }^{4}$ Техният баща, Вълко Куртович (наричан „Малки Вълко“), е известен джелепин ${ }^{5}$ и бегликчия ${ }^{6}$, познат и добре приет в османската столица и султанския дворец,

(C) Левкова-Мучинова, М., 2015 
уважаван член на православната община в Пловдив, щедър дарител за православните духовни и просветни институции

Никола Вълкович Чалъков (Чалики) е роден в Пловдив през 1819 г. Учи в гръцкото училище в Пловдив, след завършването на което е изпратен, заедно с брат си Атанас, да продължи образованието си в Париж (през 1828-1836 г.) ${ }^{8}$.

След смъртта на Вълко Куртович (1837) семейството, заедно със завърналите се от Франция синове, се установява в Пловдив. Скоро след това Никола Вълкович Чалики заминава за Одеса, където учи на собствени разноски в Ришельовския лицей и получава руско поданство 9 . От този период датират и близките му приятелски връзки с Найден Геров, които се запазват през целия им живот ${ }^{10}$, както и с Георги С. Раковски, познанството му с когото датира от есента на 1841 г., когато на път от Одеса за България Никола В. Чалики се отбива в Галац и Браила, за да предаде на участниците в браилския бунт текста на клетвата и инструкции ${ }^{11}$.

В съдружие с братовчед си Георгаки Стоянович Чалоглу ${ }^{12}$ през следващите години Никола Чалики се заема с джелепльк. Заедно с брат си Атанас Чалики са доверени служители и съветници в търговските и откупвачески предприятия на Георги С. Раковски, който в края на 40 -те и началото на 50 -те години откупува русуматите ${ }^{13}$ от Пловдивско, предприема опити да открие спиртна фабрика и проучва възможностите за откупуване на самоковските рудници, и т.н. ${ }^{14}$

По време на Кримската война (1853-1856) Никола Чалики, като руски поданик, е принуден да напусне Османската империя и да бяга в Белград, където престоява около шест месеца. Край на този принудителен престой слага смъртта на брат му Атанас и сестра му Рада ${ }^{15}$. Със съдействието на австрийския консул в София Никола Чалики се завръща в Пловдив, за да се погрижи за семейството си, ськрушено от загубата на близките си и пострадало извънредно много от непрестанните военновременни конфискации ${ }^{16}$.

След края на Кримската война Никола В. Чалики изпълнява (1860-1861) задълженията на драгоман при австрийското вицеконсулство в Пловдив ${ }^{17}$. По-късно е назначен за драгоман при руското вицеконсулство в Пловдив с право да замества Найден Геров ${ }^{18}$, когато той отсъства и изпълнява тази длъжност в продължение на 13 години (1864-1877) ${ }^{19}$. Работата му е свързана с чести пътувания до Цариград и Одрин, където той е добре приет в руските дипломатически кръгове и се радва на благоразположението на генерал Н. Игнатиев. За своята добра служба е отличен със златен медал от руското правителство ${ }^{20}$.

Значима и разностранна е обществената дейност на Никола Вълкович Чалики. Още през 1844 г. го виждаме между спомоществователите за издаването на книгата „Православно учение“ от Иларион Стоянов (по-късно митрополит Макариополски) ${ }^{21}$. Спомо-

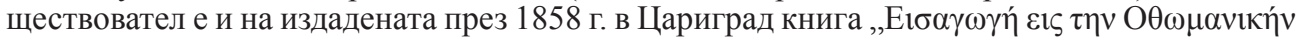

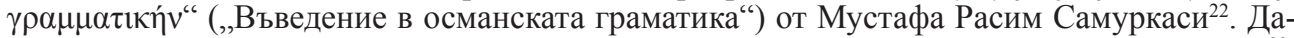
рител е на Цариградското читалище (1869) и на бедни ученици от Македония $(1871)^{23}$, училищен настоятел и касиер е на епархийското училище „Св. Кирил и Методий“ в Пловдив $^{24}$, личност с активни позиции по редица важни въпроси от живота на българите в периода от 40-те до края на 80-те години на XIX в. ${ }^{25}$

В началото на 50-те години на XIX в. Никола В. Чалики е в Цариград, където е избран между 12 членове на новосъставената българска община, конституирана около българския храм „Св. Стефан“, и в петчленното настоятелство, уредило училището при храма и изработило правилата за ежегоден избор на църковни и училищни настоятели от средите на българските еснафи в Цариград ${ }^{26}$. По-късно заедно с братовчед си д-р Стоян Чомаков ${ }^{27}$ кореспондират със софийската българска община относно развоя на църковния въпрос и инициират подаването на молба от страна на софиянци до султана, с която го молят за независима църква ${ }^{28}$.

Продължава да следи развоя на българския въпрос и по-късно, както свидетелства запазената негова кореспонденция с пловдивския представител в османската столица д-р Стоян Чомаков през 60-те години на XIX в. В поредица от писма, писани през май-юли 1861 г., Никола Чалики съветва своя братовчед д-р Чомаков за решаване на българския въпрос чрез създаването на независима българска църковна йерархия, зависима направо от Министерството на народното просвещение, по европейски модел, или чрез споразумение с австрийския посланик в Цариград за признаване от страна на българите на върховенството на Карловицкия патриарх ${ }^{29}$. 
Своите позиции по хода на българския църковен въпрос Никола В. Чалики отстоява и по-късно, като училищен настоятел в Пловдив през 1863-1864 г. и активен участник в живота на пловдивската българска община ${ }^{30}$. На събрание на пловдивските първенци на 6 февруари 1867 г. той предлага пловдивския представител в Цариград д-р Стоян Чомаков, който не се ползва вече с доверието на народа, да бъде заменен от Георгаки Стоянович Чалоглу ${ }^{31}$.

Като драгоман към руското вицеконсулство в Пловдив Никола В. Чалики е енергичен помощник на Найден Геров и защитник на българските национални интереси ${ }^{32}$. Дейността му е заслужила одобрението на високопоставените руски дипломатически кръгове и лично на руския посланик в Цариград граф Н. П. Игнатиев ${ }^{33}$. При многобройните си контакти с руските и европейските дипломатически представители в Пловдив, Одрин и Цариград той популяризира каузата на българското църковнонационално движение. Вероятно в тази връзка трябва да бъде интерпретирано и пътуването, което Никола Чалики предприема заедно с видния търговец Хр. Д. Караминков през лятото на 1863 г. в европейските столици Виена, Париж и Лондон. Официалният повод за това пътуване е лечението на Н. Чалики, но неговият маршрут, преминаващ през Белград, Париж, Виена, и осъществените по време на пътуването срещи с представители на сръбския политически елит, както и с видни български емигрантски дейци, като д-р Ив. Селимински, са следени с интерес от руските дипломатически служби, подозиращи друга цел на предприетото пьтуване ${ }^{34}$.

През 1876 г. Никола В. Чалики съставя за руското вицеконсулство обширни бележки относно грабежите и насилията над мирното население след разгрома на Априлското въстание - в което, заедно с Найден Геров, и Н. Чалики е обвинен от турските власти в съучастие ${ }^{35}$. Дейността му за запознаване на европейската и руската общественост с жестокостите при потушаването на Априлското въстание заслужава благодарственото писмо от страна на българския екзарх Антим $\mathrm{I}^{36}$.

След избухването на Руско-турската война през април 1877 г. като руски поданик, въпреки протестите на европейските посланици в Цариград, Никола Чалики е принуден от турските власти да напусне пределите на Османската държава и заминава за Атина ${ }^{37}$. През август 1877 г. е в Търново, където е определен от княз Черкаски за касиер на комисията за подпомагане на бежанците, която устройва побягналите от Тракия българи в Шипка, Дряново, Габрово и др. места, раздава им храна и средства за преживяване ${ }^{38}$.

След приключването на военните действия и подписването на Санстефанския мирен договор Никола Чалики се завръща в Пловдив, където заварва имотите си напълно разорени. Затова в поредица от писма и прошения моли руското правителство да бъде компенсиран като руски поданик за претьрпените по време на службата му като драгоман към пловдивското вицеконсулство загуби ${ }^{39}$.

Никола Вълкович Чалики има и литературни интереси. Сътрудничи в периодичния печат, където публикува свои стихове и преводи на класически произведения ${ }^{40}$.

През 1881 г. Никола Вълкович Чалики - „Първият дипломат от многобройния Чалъков род“411, заболява тежко и почива десет години по-късно, през април 1891 г. в Пловдив, без да създаде семейство и без да остави наследници ${ }^{42}$.

Не по-малко интересна и значима е личността на неговия брат Атанас Вълкович Чалъков (Чалики), роден през 1821 г. в Пловдив ${ }^{43}$.

Атанас учи в пловдивското гръцко училище, а през 1836 г. постьпва в училището на T. Каирис на о. Андрос ${ }^{44}$. По-късно заедно с брат си Никола е изпратен да продължи образованието си в Париж, където престоява няколко години (1828-1836) ${ }^{45}$.

След завръщането си в отечеството, по сведения на неговия брат д-р Георги Вълкович, Атанас Чалики се сражавал за свободата на о. Крит, а през 1845 г. участвал в опита на неколцина цариградски българи да освободят Неофит Бозвели от манастирския затвор на о. Халки ${ }^{46}$. Този интересен епизод от неговата биография е, за съжаление, оскъдно документиран ${ }^{47}$. Според сведенията, с които разполагаме, българите нападнали манастира и се опитали да изкъртят вратата на затвора, но при заплахата от отпор на местното население влезли в черквата и се престорили на черкуващи се миряни. Участниците в този смел акт били задържани, но благодарение на търновския представител, който бил румънски поданик, повечето от тях, между които и Атанас Чалики, били освободени.

След тази случка оставането на Атанас Чалики в Османската империя се оказва невъзможно, поради което той се озовава при брат си Никола в Одеса, където вероятно също се захваща с търговия, като същевременно учи в Ришельовския лицей ${ }^{48}$. През 1846-1848 г. 
е отново в Пловдив и в качеството си на бегликчия, като представител на чичо си Стоян Чалъков („Големи Стоян“")49, обикаля заедно с брат си Никола Северна България - Троянско, Плевенско, Врачанско и др., във връзка с преброяването на овцете и козите ${ }^{50}$. От 1849 г. двамата братя Чалики са близки сьтрудници на Георги С. Раковски в откупуването на данъците (русумати) от Пловдивско. Атанас Чалики е помощник на Г. С. Раковски във всички негови предприятия, с 20 хил. гроша годишна заплата ${ }^{51}$. Запазената негова кореспонденция от втората половина на 40-те и началото на 50-те години на XIX в. разкрива дейното му участие в стопанските дела на Раковски, на когото помага с важни сведения, препорьки и ценни сьвети ${ }^{52}$.

По същото време Атанас Чалики участва активно и в обществените дела на своите сънародници в Пловдив. На 16 април 1850 г. заедно с останалите Чальковци и фамилията Гешови той подписва заявлението до пловдивския митрополит с искане за въвеждане на обучение и на български език в общото гръцко училище в Пловдив ${ }^{53}$. Обществената му дейност е високо оценена от Г. С. Раковски, който пише на страниците на в. „Дунавски лебед“ за Атанас Чалики, че „първи от младих е увел и разпространил български народен дух“" в Пловдив ${ }^{54}$.

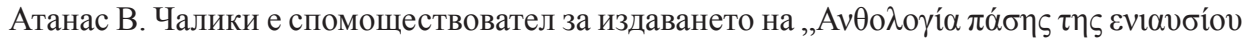
$\varepsilon \kappa \kappa \lambda \eta \sigma 1 \alpha \sigma \tau 1 \kappa \eta ́ \varsigma ~ \alpha \kappa o \lambda o v \theta i ́ \alpha \varsigma “$ („Пълна антология на годишната църковна служба“) от Па-

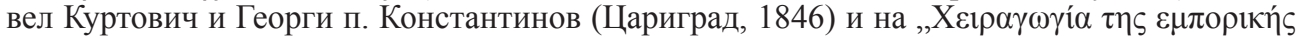

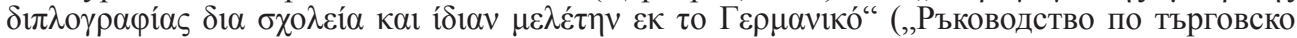
двойно счетоводство за училища и самостоятелно изучаване от немски“) от К. Янцули (Виена, 1849) ${ }^{55}$.

Житейският път на Атанас Вълкович Чалики приключва твърде рано - през втората половина на 1853 г. в Пловдив ${ }^{56}$.

Направеният преглед на живота и обществената дейност на двама видни пловдивски българи от XIX в. позволява да се откроят някои същностни характеристики от процеса на формиране на българската възрожденска интелигенция. Подготовката на братята Никола и Атанас Чалики в Ришельовския лицей в Одеса показва един от основните източници на образование за младите българчета през 40-те години на столетието и по-късно - учебните заведения на Русия, и оттам - сближаване с руската култура и политика. Обучението на двамата братя в Ришельовския лицей съвпада с началото на засиления интерес на българите към това престижно учебно заведение през 40-те години на XIX в. Неслучайно сред неговите възпитаници тогава са бъдещите известни български интелектуалци Н. Геров, С. Палаузов, Ив. Богоров и др. Сред първите българи възпитаници на Ришельовския лицей са и братята Никола и Атанас Чалики. Доброто образование ги нарежда между най-образованите техни сънародници в Пловдив и в значителна степен определя по-нататьшния им житейски път на интелектуални и политически търсения. Особено силна е тази връзка в живота на Никола В. Чалики, която се запазва през целия му житейски път чрез дългогодишната му работа като драгоман към Руското консулство в Пловдив, контактите с видни руски дипломати и наградите, получени от руското правителство. От годините, прекарани в Одеса, вероятно датира и познанството му с Найден Геров, което ще прерасне в близко сътрудничество в обществено-политическата и културната сфера. На годините, прекарани в Ришельовския лицей, Н. Чалики дължи и запознанството си с руската и западноевропейската литература и култура, мотивирало и неговите литературни опити, публикувани на страниците на възрожденската периодика. Активните позиции на братята Чалики в обществения живот са пример за качествата на формиращата се новобългарска интелигенция - добре образована и активно ангажирана в решаването на най-актуалните проблеми на своето съвремие.

${ }^{1}$ Генчев Н. Българското възраждане. - 4. доп. изд. - София, 1995. - С. 163-167.

${ }^{2}$ Попруженко М. Г. Одеса и българското възраждане. // Климент Търновски - Васил Друмев. За 25-годишнината от смъртта му. Изследвания, спомени и документи / Под ред. на проф. М. Арнаудов. - София, 1927. - С. 87-100; Поглубко К. А. За да бъдат полезни на народа си... - София, 1976. - С. 33 48; Радкова Р. Просветни центрове за българите през Възраждането вън от пределите на страната // България в света от древността до наши дни. - Т. 1. - София, 1979. - С. 442-443; Сохан П. С. Очерци по история на украинско-българските връзки. - София, 1979. - С. 75-76; Бъчварова Н. Възпитаници на южноруските училища и развитие на научните знания в България (XIX в.). - София, 1989. - С. 17 19; Налбантова Ел. Одеса в българската история и литература на XIX век. - Одеса, 2006. 
${ }^{3}$ По-подробно за възникването и развитието на това учебно заведение през ХІХ в., както и за училите в него българи вж. Бъчварова Н. Възпитаници на южноруските училища... - C. 19-28.

4 За тях вж. Мирчева К. Чалъкови // Кой кой е сред българите XV-XIX в. / Под ред. на Ил. Тодев. - София, 2000. - С. 290-296; Научен архив - БАН, сб. IV, а.е. 35 (Кепов Ив. Живот и дейност на Чалъковци и тяхното потомство (Родословно изследване). - София, 1935) (машинопис), л. 279; Левкова-Мучинова М. Родът Чалъковци през Възраждането: дисертация за присъждане на образователна и научна степен „доктор“. - София, 2012; Мучинов В. Демографска характеристика на един български възрожденски род (родът Чалъковци през втората половина на XVIII и през XIX век) / В. Мучинов, М. Левкова-Мучинова // Семейство и солидарност между поколенията. Научна конференция (София, 17-18 октомври 2012 г.). - София, 2013. - С. 27-34.

5 Джелепкешаните (джелепи) са категория население със специален статут в османската държава, които срещу известни данъчни облекчения - освобождаване от извънредните данъци (аваризи), от беглик и гюмрук (мито), са задължени да доставят годишно на фиксирани ниски цени определен брой дребен рогат добитък за нуждите на армията, столицата и големите градове.

${ }^{6}$ Бегликчиите са откупвачи на десятъка (ондалък, беглик) върху дребния рогат добитък в Османската империя.

7 За него вж. Мирчева К. Чалъкови... - С. 292; Левкова-Мучинова М. Родът Чалъковци през Възраждането... - С. 76-79. Вълко Куртов има още двама синове - д-р Георги Вълкович и д-р Александър (Алеко) Вълкович, които обаче получават образованието си във Военно-медицинското училище в Цариград, поради което техният живот и дейност ще бъдат разглеждани другаде (вж. Левкова-Мучинова М. Родът Чалъковци през Възраждането... - С. 134-139).

${ }^{8}$ Кепов Ив. Живот и дейност на Чалъковци..., л. 279; Мирчева К. Чалъкови... - С. 294.

${ }^{9}$ Мирчева К. Чалъкови... - С. 294.

${ }^{10}$ Кепов Ив. Живот и дейност на Чальковци..., л. 279.

${ }^{11}$ Вж. Попруженко М. Г. Материали по историята на възраждането на България. // Юбилеен сборник по случай 25-годишнината от първия випуск на габровската Априловска гимназия. Пловдив, 1900. - С. 89, 93; Романски С. Заговорът на Г. С. Раковски (Георги Македон) в Браила през 1842 година. // Сборник на БАН. - Кн. 14. - Клон историко-филологичен и философско-обществен. - София, 1921. - С. 99; Архив на Г. С. Раковски. - Т. 2. - София, 1957. - С. 82-83.

12 За него вж. Мирчева К. Чалъкови... - С. 293-294; Левкова М. Възрожденецът Георги Стоянов Чалъков // Годишник на Регионален исторически музей - Пловдив. - Книга 6: Доклади от научен форум „Пловдивски приноси 2009“ на тема „Род, семейство, отечество“ (Пловдив, 7-8 октомври 2009 г.). - Пловдив, 2009. - С. 31-34.

${ }^{13}$ Русумати (тур.) - косвени данъци.

${ }^{14}$ Вж. Архив на Г. С. Раковски. - Т. 1. - София, 1952. - С. 64-65; Архив на Г. С. Раковски. - Т. 2. - С. 82-83, 97, 105-106; Из архивата на Найден Геров / Под ред. на Т. Панчев. - Кн. 2. - София, 1914. - C. 916.

${ }^{15}$ Рада (Ралу) Вълкович (ок. 1826-1854) - дъщеря на Вълко Куртов и Елисавета х. Костова. Омъжена през 1854 г. за Стоян (Цоко) Каблешков от копривщенския род Каблешкови и починала в края на същата година при раждане (вж. Кепов И. Живот и дейност на Чалъковци..., л. 292-293; ЛевковаМучинова М. Родът Чалъковци през Възраждането... - С. 135).

${ }^{16}$ Кепов Ив. Живот и дейност на Чалъковци..., л. 279-281.

17 Вж. Русия и българското националноосвободително движение 1856-1876. -Т. 1. - Ч. 1. София, 1987. - С. 132.

18 По-подробно за откриването на руското вицеконсулство в Пловдив вж.: Кирилова А. Откриване на руското консулско агентство в Пловдив през 1857 година // Исторически преглед. - 2009. - Кн. 1-2. - С. 48-76.

${ }_{19}^{19}$ Въпреки ходатайството на пловдивския руски вицеконсул Найден Геров, в продължение на десет години Никола Чалики изпълнява тази служба без заплащане. Едва през 1874 г. му е определена заплата от руското правителство (вж. Кепов Ив. Живот и дейност на Чалъковци..., л. 283).

${ }^{20}$ Пак там, л. 283-284.

${ }^{21}$ Начов Н. Цариград като културен център на българите до 1877 година. - София, 1925. - С. 14.

${ }^{22}$ Вж. Стоянов М. Стари гръцки книги в България. - София, 1978. - С. 241.

${ }^{23}$ Турция. -1871 . - Г. VII. - Бр. 39. - 16 ноем.

${ }^{24}$ Груев Й. Епархийското в Пловдив училище „Св. Кирил и Методий“ // Български преглед. Г. ІІІ. - Кн. 7-8. - София, 1896. - С. 137; Русия и българското националноосвободително движение... - Т. 2. - София, 1990. - С. 43.

${ }^{25}$ Кепов Ив. Живот и дейност на Чальковци..., л. 284; За Никола В. Чалики вж. още: Райчевски Г. Пловдивска енциклопедия. - 3. прераб. и доп. изд. - Пловдив, 2004. - С. 365.

${ }^{26}$ Архив на Г. С. Раковски. - Т. 2. - С. 86-87; Кепов Ив. Живот и дейност на Чалъковци..., л. 280.

27 Д-р Стоян Чомаков е виден български общественик с големи заслуги за решаването на българския църковнонационален въпрос. По-подробно за него вж. Тодев Ил. Д-р Стоян Чомаков (18191893). Живот, дело, потомци. - Ч. 1: Изследване. - София, 2003. 
${ }^{28}$ Кепов Ив. Живот и дейност на Чалъковци..., л. 281.

${ }^{29}$ Според Н. Генчев, това предложение е било вероятно внушено от Найден Геров и е имало за цел да упражни натиск върху патриарха и турското правителство за решаване на българския църковен въпрос (вж. Генчев Н. Възрожденският Пловдив (Принос в българското духовно Възраждане). Пловдив, 1981. - С. 225). Ил. Тодев пък смята, че зад този проект стои Австрия в лицето на австрийския вицеконсул в Пловдив Берти: Тодев Ил. Д-р Стоян Чомаков... - Т. 1. - С. 166-167.

${ }^{30}$ Генчев Н. Възрожденският Пловдив... - С. 229.

${ }^{31}$ Кепов Ив. Живот и дейност на Чалъковци..., л. 283-284.

${ }^{32}$ Вж. Из архивата на Найден Геров... - Кн. 2. - С. 781-782.

${ }^{33}$ Пак там. - Кн. 1. - С. 648-649, 763-764.

34 Руският консул в Белград Влангали например изисква от Сава Филаретов в София „сведения за тая личност, между прочем и за това, коя е истинната причина на неговото отиване в Париж“" (вж. Из архивата на Найден Геров... - Кн. 1. - С. 78; Кн. 2. - С. 625, 719).

${ }^{35}$ Кепов Ив. Живот и дейност на Чалъковци..., л. 284.

${ }^{36}$ Маркова 3. Българската екзархия 1870-1879 // Маркова 3. Избрани съчинения. - Т. 1. - София, 2007. - C. 452

${ }^{37}$ Вж. Из архивата на Найден Геров... - Кн. 1. - С. 22; Кн. 2. - С. 780-781.

${ }^{38}$ Пак там. - Кн. 2. - С. 782.

${ }^{39}$ Пак там. - С. 786. Впоследствие руското правителство му признава 44491 зл. лева военновременни загуби, които започва да му изплаща на части (Кепов Ив. Живот и дейност на Чалъковци..., л. 286).

${ }^{40}$ Вж. „Жалба“ - „Сочинил по подражанию Шилера Н. Ч. [Никола Чалики]“ // Цариградски вестник. - 1853. - Г. ІІІ. - Бр. 114. - 21 март; „Что слава? Адская заплата...“// Цариградски вестник. - 1855. - Г. V. - Бр. 224. - 14 май; „Комит или опашята звезда“ // Български книжици. - 1858. - Г. I. Част 3. - Кн. 19. - окт. - С. 131-135; Свои стихове Никола В. Чалики помества и в отпечатаната през 1858 г. в Белград от М. Л. [Лазаров] Софиянец „Разна любовна песнопевка“.

${ }^{41}$ Според определението на Ив. Кепов (вж. Кепов Ив. Живот и дейност на Чалъковци..., л. 285).

42 Пак там, л. 286.

${ }^{43}$ Пак там, л. 287.

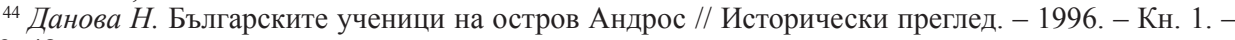
C. 39,48 .

${ }^{45}$ Мирчева К. Чалъкови... - С. 294.

${ }^{46}$ Кепов Ив. Живот и дейност на Чалъковци..., л. 287. Вж. също Арнаудов М. Неофит Хилендарски Бозвели 1785-1848. Живот - дело - епоха. - София, 1930. - С. 676; Иречек К. Български дневник. - Т. 1: 1879-1881. - София, 1995. - С. 510.

47 Според сведенията на архимандрит Онуфрий инициативата за освобождаването на Неофит Бозвели принадлежи на първомайстора на българския абаджийски еснаф в Цариград Н. Сапунов (Известия на историческото дружество в София. - 1911. - Кн. 3. - С. 63). Различните източници посочват различен числен състав на участниците в това събитие, който се колебае между 5-6 и 80 души (вж. Кепов Ив. Живот и дейност на Чалъковци..., л. 287-288).

${ }^{48}$ Кепов Ив. Живот и дейност на Чалъковци..., л. 288. Вж. също: Из архивата на Найден Геров... - Кн. 2. - C. 67-68.

49 За него вж. Левкова $M$. Традиция и модерност в житейския път на Стоян Тодоров Чалъков (1768-1850) // Известия на Старозагорския исторически музей. - Т. 4: Личността в историята. Сборник с доклади и съобщения от Националната научна конференция, посветена на 200 г. от рождението на Александър Екзарх, Захарий Княжески и Атанас Иванов (22-23 април 2010 г., Стара Загора). Стара Загора, 2011. - С. 394-401.

${ }_{50}$ Вж. напр.: Български исторически архив при Национална библиотека „Св. св. Кирил и Методий“ - София, ф. 782, а.е. 97, л. 93а; Из архивата на Найден Геров... - Кн. 2. - С. 820.

${ }^{51}$ Петров Б. Биография на Георги Стойков Раковски. - София, 1910. - С. 54; Кепов Ив. Живот и дейност на Чальковци..., л. 289-291.

52 Вж. Киселков А. Из живота на Раковски в Цариград // Списание на БАН. - 1923. - Кн. 26. С. 108-116; Архив на Г. С. Раковски. - Т. 2. - С. 72-73, 79-84, 88-92, 97, 98-100; Трайков В. Георги Стойков Раковски. Биография. - София, 1974. - С. 97-98.

${ }^{53}$ Кепов Ив. Живот и дейност на Чалъковци..., л. 291. C. 97.

54 Дунавски лебед. - 1860. - Бр. 8. - 1 ноем.; Вж. също Трайков В. Георги Стойков Раковски... -

${ }_{55}^{5 \%}$ Вж. Стоянов М. Стари гръцки книги в България... - С. 193, 210.

${ }^{56}$ Вж. Писмо на Стоян Д. Каблешков - от Пловдив, до Г. С. Раковски в Цариград, от 20 май 1853 г. // Архив на Г. С. Раковски. - Т. 2. -С. 105; Вж. също Кепов Ив. Живот и дейност на Чалъковци..., л. 291. 